\title{
The impact of the fipronil crisis on the financial performance of Dutch laying hen farms
}

\author{
Jaap Sok $^{1 *} \mathbb{D}$, Peter van Horne ${ }^{2}$ and Miranda Meuwissen ${ }^{1}$
}

\begin{abstract}
Background: Illegal use of fipronil as an insecticide in 2017 has caused substantial damage to Dutch laying hen farms. We assessed how the fipronil crisis has affected the financial performance of affected farms as well as unaffected farms. While affected farms faced culling their flocks and lost revenue, unaffected farms benefitted from temporary high egg prices.

Methods: A three-step normative modelling approach is taken using financial statements and a partial budget. The estimations are for a 50,000 laying hen farm facing the fipronil crisis for 5 months. First, a baseline is created by generating an income statement of this laying hen farm representing a 'normal year'. Second, incremental costs and revenue as a result of the fipronil crisis are estimated. Third, the baseline income statement is updated with the outcomes of the partial budget. This results in two additional income statements that report the net operating result of this farm being unaffected and affected by the fipronil crisis.

Results: While in a normal year this average-sized farm has a net operating result of around 18,000 euros, profitability was estimated to be $-369,000$ euros and $+169,000$ euros for the affected and unaffected farm due to the crisis respectively. For affected farms, impacts were especially high as there was no government compensation or insurance.

Conclusions: As Dutch farms typically operate as independent family farms, there was also no compensation from other chain actors. The affected farms therefore likely have faced financial distress and have had to increase debt or use their financial reserves for household consumption and restarting the business. Outcomes contribute to discussions around liability claims and cost-benefit assessments of measures to improve the chain food safety and rapid alert systems.
\end{abstract}

Keywords: Fipronil crisis, Financial performance, Financial distress, Partial budget, Laying hen, Family farm

\footnotetext{
*Correspondence: jaap.sok@wur.nl

1 Department of Social Sciences, Business Economics, Wageningen

University, Wageningen, The Netherlands

Full list of author information is available at the end of the article
}

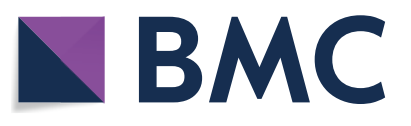

(c) The Author(s) 2020. This article is licensed under a Creative Commons Attribution 4.0 International License, which permits use, sharing, adaptation, distribution and reproduction in any medium or format, as long as you give appropriate credit to the original author(s) and the source, provide a link to the Creative Commons licence, and indicate if changes were made. The images or other third party material in this article are included in the article's Creative Commons licence, unless indicated otherwise in a credit line to the material. If material is not included in the article's Creative Commons licence and your intended use is not permitted by statutory regulation or exceeds the permitted use, you will need to obtain permission directly from the copyright holder. To view a copy of this licence, visit http://creativeco mmons.org/licenses/by/4.0/. The Creative Commons Public Domain Dedication waiver (http://creativecommons.org/publicdomain/ zero/1.0/) applies to the data made available in this article, unless otherwise stated in a credit line to the data. 


\section{Background}

The use of a newly introduced insecticide to combat red mite led to a crisis in 2017 in the laying hen sector in The Netherlands after the insecticide was found to contain fipronil. Fipronil is allowed as an insecticide against lice for dogs and cats, but not for animals in food chains [1]. Public health risk was, according to the European Food Safety Authority, considered to be low; to exceed the level of toxicity $(0.72 \mathrm{mg} / \mathrm{kg})$, an adult $(80 \mathrm{~kg})$ would need to eat more than 17 jumbo eggs a day [2]. However, due to a large number of laying hen farms affected and the substantive amount of already exported eggs, the impact on the laying hen sector was large. More than 300 farms were temporarily shut down until it was proven that the stables were free from fipronil again, and more than 100 million eggs were discarded. Also, as forced moulting of laying hens appeared to be ineffective, more than 3 million chickens were culled. Even more, to regain consumer confidence in food safety, table eggs originating from The Netherlands, among others, were recalled in Germany.

The fipronil crisis did not only affect laying farms. The Dutch egg chain consists of several stages that work closely together [3]. Prior to laying hen farms, specialized breeding farms produce fertilized eggs; these eggs go to a hatchery, and the new-born chickens go to rearing farms. The young hens arrive at the laying hen farms a few weeks before the egg production cycle starts. Eggs are sorted and packaged by on-farm or specialized packing stations and then sold to various companies in retail, foodservice, processing (egg products), and export.

Concerning the farm-economic consequences of the fipronil crisis, losses for affected farms, i.e. farms on which the new insecticide was applied, differed from previous crises in the poultry sector such as outbreaks of epizootics and dioxin contaminations in poultry feed. Concerning the latter, poultry were not culled thereby leading to lower costs at the farm level [4]. In the case of epizootics, such as avian influenza, whole flocks are culled, but affected farms receive compensation from public-private animal health funds [5], often augmented with pay-outs from business interruption insurance to cover losses due to standstill [6]. During the fipronil crisis in The Netherlands, affected laying hen farms did not receive any indemnification. In contrast, unaffected farms benefitted from the fipronil crisis because of the temporary shortage of eggs and resulting high market prices.

In this article, our aim is to assess how the fipronil crisis has affected the financial performance of both affected and unaffected farms. Concerning affected farms, these insights are useful in the context of liability claims, for example. Outcomes also contribute to cost-benefit considerations that can further improve chain quality programs and alert systems. Moreover, benefits at unaffected farms are relevant in case of solidarity funds, as discussed in the aftermath of avian influenza outbreaks [6].

\section{Methods \\ Modelling approach}

A normative modelling approach is taken, as laid out in Fig. 1, using financial statements and a partial budget. Farm-economic consequences are estimated in the context of the Dutch laying hen sector, which is dominated by family farms. The first step is to create a baseline by generating an income statement of a laying hen farm representing a 'normal year'. The income statement is a 'report of revenue and expenses ending with an estimate of net farm income' and 'provides an estimate of the value of products and services produced during an accounting period and the costs of the resources used to produce them' [7].

We use a partial budget framework [7] in step 2 to estimate changes in farm income in a 'normal' year as a result of the fipronil crisis. We answer the following four questions:

1. What new or additional costs occurred [due to the Dutch fipronil contamination]?

2. What costs were reduced or eliminated [...]?

3. What new or additional revenues were received [...]?

4. What revenues were forgone $[. .$.$] ?$

Partial budgeting is a form of marginal analysis as we assume that a fipronil contamination does not affect other decision-making aspects of the farm, such as the depreciation of a poultry house or the debt repayment schedule. The focus is on incremental costs and revenue. While in principle all four categories of the partial budget apply to both contamination states, for an unaffected laying hen farm only the category of additional revenue (question 3) is relevant. Outcomes of the partial budget model are used in step 3 and result in two updated income statements in addition to the baseline; one reports the income of an unaffected farm, the other of an affected farm. We analyse the impact of the fipronil crisis on financial performance using two indicators. First, we calculate the net operating result, which is 'a criterion of profitability (also known in the sector as rentability) and thus indicates the remuneration for management and risk' [8]. The net operating result represents the income available to provide a return to the production factors of capital (equity), labour, and management of the owner(s). Second, we calculate the earnings before interest, taxes, depreciation, and amortization (EBITDA). The latter is often 


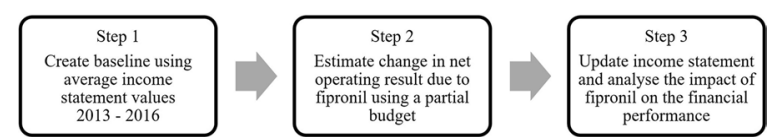

Fig. 1 Three research steps to assess the impact of the fipronil crisis on the financial performance of an affected and unaffected farm

used as a proxy for operating cash flow to measure the cash available to meet financial obligations [9].

\section{Data availability}

Mainly two sources of data are used: farm accountancy data of Dutch laying hen farms publicly available from Wageningen Economic Research [10] via the Agro \& Food portal (https://www.agrimatie.nl) and a commonly used reference guide (KWIN) that contains all sorts of quantitative base values that advisors, farmers, students, or researchers use to perform financial analyses [11]. The 'Agrimatie' database is mainly used to create the income statement baseline (step 1, Fig. 1, and Table 2 'normal year'). The KWIN guide is mainly used to calculate the different incremental cost and revenue factors in the partial budget model (step 2, Fig. 1, and Table 1). Some other references used for input values are a report that was prepared for the Dutch Ministry of Agriculture, Nature, and Food Quality by Horne et al. [12] and a report prepared by the Poultry Expertise Center (PEC), which is a publicprivate partnership in the Dutch poultry sector among companies, government bodies, and educational institutions [13].

\section{Assumptions and delimitation}

Economic consequences of a fipronil contamination depend on a range of factors that we cannot all take into account. Our perspective is the individual laying hen farm and not the egg supply chain. Most of our data consist of averages. We therefore work with a flock size of 50,000 hens [10]. We estimate incremental revenue and costs for the most adopted (60\%) housing system in 2017, which is the 'barn', a floor housing system in which hens can move freely, as opposed to the cage system in which hens are confined in an 'enriched cage'. In the barn system, hens have no outdoor access as opposed to the 'freerange' and 'organic' housing system [14].

The income statements are made up for the year 2017, while for the partial budget we consider 5 months (Fig. 2). The first contaminated fipronil eggs were reported by the end of July in Belgium [15] and soon thereafter in The Netherlands. Farmers who treated their housing system with fipronil to control red mite infestation were temporarily shut down; consequently, no eggs, hens, or manure could leave the farm. Mainly two measures at the farm level were suggested to become free from fipronil: culling or forced moulting. The latter strategy is rational to take if the flock is still early in its egg production cycle. However, moulting often was not effective to get the hens free from fipronil making culling still needed [12]. Hence, we base incremental costs and revenue on a culling strategy.

Concerning depreciation of the flock, culling implies that the old flock is more quickly depreciated. The flock is assumed to have an egg production period of 68 weeks, starting 1 January 2017. For the treatment and reporting of depreciation, we follow Poppe [8] and regard depreciation as a fixed cost.

Concerning egg prices, we use the average price over the first 6 months of 2017 ( $€ 7.8 / 100$ eggs) and the average price of the last 4 months of 2017 ( $€ 10.3 / 100$ eggs) to calculate additional and reduced revenue from selling eggs for the farm being affected and unaffected. Figure 3 provides an overview of monthly egg prices from 2013-2017, the first 4 years as monthly averages. In the first quarter, the monthly egg prices in 2017 were below the 4-year average (2013-2016), while in the second quarter this was the opposite. However, since we express the impact on the operating result in a year, the monthly variation is less important for our calculations. Based on the egg price series data, a price level of $€ 7.8 / 100$ eggs well represents the price level in a 'normal year'.

Additional file 1 can be accessed to examine the input values and verify the calculations made for the partial budget and income statements.

Table 1 Partial budget over the period 31 July 2017-31 December 2017 of the impact of fipronil on the net operating result (50,000 laying hens)

\begin{tabular}{lll}
\hline & Unaffected farm & Affected farm \\
\hline Additional costs & $€ 0$ & $€ 113,965$ \\
Fipronil manure disposal & & $€ 10,180$ \\
Poultry house cleaning & & $€ 10,000$ \\
Contaminated eggs disposal & & $€ 8056$ \\
Old flock disposal & & $€ 40,000$ \\
Old flock lump sum write-off & & $€ 45,729$ \\
Reduced costs & $€ 0$ & $€ 204,894$ \\
Feed & & $€ 200,099$ \\
Manure disposal & & $€ 4796$ \\
Additional revenue & $€ 150,886$ & $€ 0$ \\
Selling eggs & $€ 150,886$ & \\
Reduced revenue & $€ 0$ & $€ 477,946$ \\
Selling eggs & & $€ 459,796$ \\
Slaughter value hens & & $€-387,017$ \\
Change in net operating result & $€ 150,886$ & \\
\hline
\end{tabular}




\section{Results}

We start by presenting the partial budget results for the 5 months as laid out in Table 1. An unaffected laying hen farm operating under 'normal' circumstances in 2017 had no additional or reduced costs. The only way fipronil impacted the financial performance is via the revenue side: these farmers received over the last 5 months of 2017 a substantially higher price for their eggs (on average $€ 2.6 / 100$ eggs). The change in net operating result for an unaffected laying hen farm is estimated at $€ 150,886$, which is about 8.5 times the net operating result in a 'normal year'.

In contrast, an affected laying hen farm had considerable additional costs. About $40 \%$ of these costs relate to depreciation, more specifically the lump sum write-off of culled hens. Instead of 52 weeks of depreciation in a normal year, the full useful life (production cycle) of 68 weeks had to be depreciated. The other $60 \%$ entailed specific costs made for the cleaning of the poultry house and the disposal of hens, eggs, and manure. However, there were fewer additional costs than reduced costs. With the culling of the flock, feed was saved while less manure had to be disposed of. The biggest cause for the negative change is at the revenue side, i.e. the production standstill of about 5 months causes an estimated drop in revenue of $€ 477,946$. A small fraction of the reduced revenue is due to the slaughter value forgone as the hens had to be culled and disposed of. The change in net operating result for an affected laying hen farm is estimated at $€$ $-387,017$.

At this point, we would like to emphasize the impact of depreciation costs on the net operating result. We consider only changes in revenue and costs in the year 2017. In our calculations, only 16 weeks of depreciation had to be written off extra for an affected farm, as we assumed the flock to have an egg production period of 68 weeks, starting as of January 1 . Suppose the flock were younger, thus earlier in its production cycle at the start of the shutdown period (Fig. 2); then the old flock lump sum writeoff would have been much higher. Costs of depreciation increase with $€ 2858$ per week.

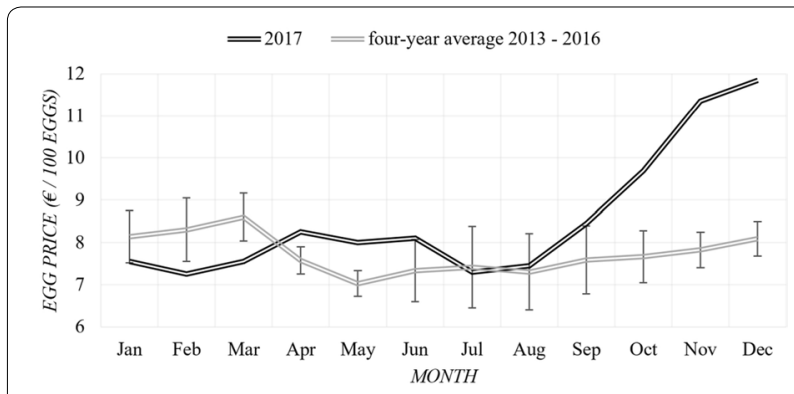

Fig. 3 Egg price series monthly data from 2013-2017 [10]

Table 2 presents the income statement over the whole year of 2017 in which we report the net operating result estimation of a laying hen farm in a 'normal' year. The net operating result we estimate in a normal year is $€ 17,729$. One should note that there have been quite some fluctuations in the annual net operating result figures over the last years in the laying hen sector including $€-112,600$ in $2013, € 20,200$ in $2014, € 130,200$ in 2015 , and $€ 101,100$ in 2016 [10]. Note also that the average of the aforementioned income figures slightly differs from our estimation because of a different income format used to calculate depreciation of the flock.

The outcomes of the partial budget are inserted into the income statement figures, allowing to calculate the net operating result for a laying hen farm being unaffected or affected by the fipronil crisis. Due to the higher selling prices, the returns for an unaffected farm increased by more than $15 \%$ compared to the returns in a normal year. Since the cost structure is not impacted, the net operating result is more than nine times higher, while the EBITDA almost doubled.

For an affected farm, both revenue and costs changed considerably. The turnover from selling eggs for an affected farm decreased by more than $40 \%$. Allocated costs initially increased because of the additional costs of the cleaning of the poultry house and the disposal of hens, eggs, and manure. But the reduced cost factor of feed of $€ 200,099$ resulted in an overall decrease in the

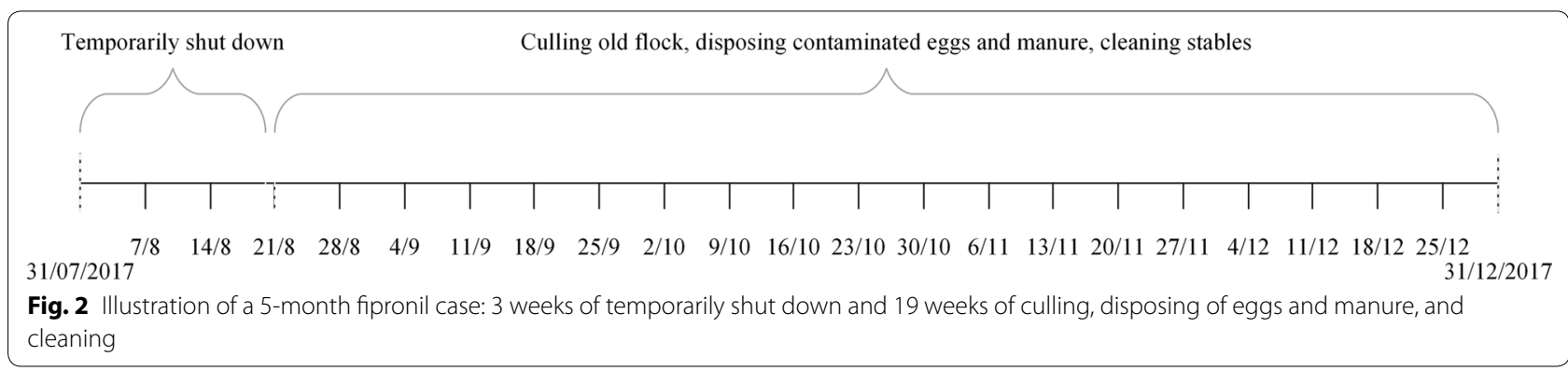


allocated costs of $€ 136,658$ compared to the allocated costs in a normal year.

The gross margin (revenue minus variable costs) is not large enough to cover fixed costs. The latter increased substantially for an affected farm as the fipronil contaminated flock was culled, and the remaining book value and anticipated slaughter (salvage) value had to be written off as a lump sum. The net operating result of an affected laying hen farm is estimated at $€-369,287$ and the EBITDA at $€-231,862$.

The profitability calculated under a normal year is too low to provide satisfactory returns to the unpaid production factors of the owner's capital, management, and labour. The average equity of a Dutch laying hen farm over 2013-2016 was $€ 743,175$ [10]. A net operating result of $€ 17,729$ is not enough to provide remuneration for this amount of capital as well as for the labour hours spent of the farmer. However, due to the fipronil crisis, unaffected farms had a profitable year with decent returns, increasing the owner's equity and working capital. Affected farms, on the other hand, most likely had to increase debt or use their financial reserves to counterbalance the negative income and make a continuation of the business possible and restart egg production with a new flock. The EBITDA estimation indicates that these farms have likely experienced financial distress after the fipronil crisis.

\section{Discussion and conclusions}

Illegal use of fipronil as an insecticide in 2017 has caused substantial damage to Dutch laying hen farms. In this article, our aim was to assess how the fipronil crisis has affected the financial performance of both affected and unaffected farms. While affected farms faced culling their flock and lost revenue, unaffected farms benefitted from temporary high egg prices. Note, however, that unaffected farms selling eggs via contracts did not benefit. Estimations are for a 50,000 laying hen farm facing the fipronil crisis for 5 months. While in a normal year this farm has a net operating result of around 18,000 euros, profitability was estimated to be $-369,000$ euros and $+169,000$ euros for the affected and unaffected farm because of the crisis respectively. For affected farms, impacts were especially high as there was no government compensation or insurance. As Dutch farms typically operate as independent family farms there was also no compensation from other chain actors. The affected farms therefore likely faced financial distress and had to increase debt or use their financial reserves for household consumption and restarting the business.

Table 2 Income statement over 2017 of a laying hen farm in a 'normal year', in a fipronil unaffected and affected state (50,000 laying hens)

\begin{tabular}{|c|c|c|c|}
\hline & Normal year (baseline) & Unaffected farm & Affected farm \\
\hline \multicolumn{4}{|l|}{ Revenue } \\
\hline Turnover (eggs) & $€ 987,350$ & $€ 1,138,236$ & $€ 527,554$ \\
\hline Other returns (meat, other business activities) & $€ 94,600$ & $€ 94,600$ & $€ 94,600$ \\
\hline Total revenue & $€ 1,081,950$ & $€ 1,232,836$ & $€ 622,154$ \\
\hline \multicolumn{4}{|l|}{ Variable costs } \\
\hline Feed & $€ 596,250$ & $€ 596,250$ & $€ 396,152$ \\
\hline Manure disposal & $€ 9625$ & $€ 9625$ & $€ 15,010$ \\
\hline Other allocated costs (e.g. maintenance) & $€ 79,600$ & $€ 79,600$ & $€ 79,600$ \\
\hline Poultry house cleaning & & & $€ 10,000$ \\
\hline Disposal contaminated eggs & & & $€ 8056$ \\
\hline Disposal costs old flock & & & $€ 40,000$ \\
\hline Total allocated costs & $€ 685,475$ & $€ 685,475$ & $€ 548,817$ \\
\hline Gross margin & $€ 396,475$ & $€ 547,361$ & $€ 73,338$ \\
\hline \multicolumn{4}{|l|}{ Fixed costs } \\
\hline Depreciation of flock & $€ 148,621$ & $€ 148,621$ & $€ 212,500$ \\
\hline Other non-allocated costs & $€ 230,125$ & $€ 230,125$ & $€ 230,125$ \\
\hline Total fixed costs & $€ 378,746$ & $€ 378,746$ & $€ 442,625$ \\
\hline \multicolumn{4}{|l|}{ Estimation of the profitability } \\
\hline Net operating result & $€ 17,729$ & $€ 168,615$ & $€-369,287$ \\
\hline \multicolumn{4}{|l|}{ Estimation of the repayment capacity } \\
\hline EBITDA (excl. depr. flock) & $€ 155,154$ & $€ 306,040$ & $€-231,862$ \\
\hline
\end{tabular}


A normative, deterministic modelling approach was taken to assess the financial performance of fipronil affected and unaffected farms. We estimated for these two farm types changes in revenue and costs based on 50,000 laying hens, which represents an average farm size. The Dutch laying hen sector in 2017 consisted of 860 farms [3], which vary in terms of size, capital structure, technical performance, innovativeness, etc. These and other characteristics all influence financial performance and the impact of a shock such as the fipronil affair. For example, large and modern farms, especially those that are financed mainly by outside capital, are committed to proportionally more depreciation and interest costs. A positive, empirical modelling approach to address the impact of these characteristics was not possible to apply; from the farm accountancy data sample, affected farms could not be distinguished from unaffected farms.

Nevertheless, estimations of the impact of the fipronil crisis on the financial performance of Dutch laying hen farms are still conservative as we only accounted for direct and visible farm-economic (monetary) consequences in 2017. At the farm level, the financial performance in (the beginning of) 2018 most likely still deviated positively from a 'normal year' for unaffected farms and negatively for affected farms. At the sector level, the financial performance of laying hen farms has been affected by efforts needed to retrieve export markets and to regain consumer trust, see e.g. [16]. Also, costs of monitoring and disruptions along the value chain were not included.

We further stress that quantifying the change in revenue and costs does not provide the full story of how the fipronil crisis has affected laying hen farm owners. The Dutch laying hen sector is dominated by family farms. Our financial analysis did not consider qualitative (non-monetary) factors, such as the farm household's feelings of shame and anger, see e.g. [17]. Reciprocal relationships exist between financial distress and psychological distress [18].

Outcomes contribute to discussions around liability claims and to cost-benefit considerations for further improving chain quality programs and alert systems. Moreover, benefits at unaffected farms are relevant in case of solidarity funds, as discussed in the aftermath of avian influenza outbreaks [6].

\section{Supplementary information}

Supplementary information accompanies this paper at https://doi. org/10.1186/s13071-020-04458-8.

Additional file 1. Fipronil input values and calculations.

\section{Acknowledgements}

The authors thank the reviewers for the constructive comments on an earlier draft.

\section{Author contributions}

JS: conceptualisation, methodology, formal analysis, writing - original draft, visualization; $\mathrm{PvH}$ : validation, writing —-review and editing); MM: conceptualisation, writing—original draft.

\section{Funding}

Not applicable.

\section{Availability of data and materials}

All data generated or analysed during this study are included in this published article [and its supplementary information files]

\section{Ethics approval and consent to participate}

Not applicable.

\section{Consent for publication}

Not applicable.

\section{Competing interests}

The authors declare that they have no competing interests.

\section{Author details}

${ }^{1}$ Department of Social Sciences, Business Economics, Wageningen University, Wageningen, The Netherlands. ${ }^{2}$ Subdivision Consumer and Chain, Wageningen Economic Research, Wageningen, The Netherlands.

Received: 4 June 2020 Accepted: 5 November 2020

Published online: 23 November 2020

References

1. Wang X, Martínez MA, Wu Q, Ares I, Martínez-Larrañaga MR, Anadón A, et al. Fipronil insecticide toxicology: oxidative stress and metabolism. Crit Rev Toxicol. 2016;46(10):876-99. https://doi.org/10.1080/10408 444.2016.1223014.

2. Munoz-Pineiro MA, Robouch P. Fipronil in eggs: factsheet. Joint Research Centre, European Commission; 2018.

3. Wageningen Economic Research: De eierketen in beeld (in Dutch). 2019. https://www.agrimatie.nl/ThemaResultaat.aspx?subpublD=2232\&thema $\mid \mathrm{D}=2270$ \&indicatorl $\mathrm{D}=2098$. Accessed 11 May 2020.

4. Meuwissen Miranda PM, Van Andel Alex LA, Van Asseldonk Marcel APM, Huirne Ruud BM. Eliciting processing industry damage from feed crises. Br Food J. 2009;111(8):878-92. https://doi.org/10.1108/000707009109809 82.

5. Longworth N, Mourits MCM, Saatkamp HW. Economic analysis of HPAI control in the Netherlands II: comparison of control strategies. Transbound Emerg Dis. 2014;61(3):217-32. https://doi.org/10.1111/tbed.12034

6. Meuwissen MPM, Assefa TT, van Asseldonk MAPM. Supporting Insurance in European Agriculture: Experience of Mutuals in the Netherlands. EuroChoices. 2013;12(3):10-6. https://doi.org/10.1111/1746-692X.12034.

7. Kay RD, Edwards WM, Duffy PA. Farm management. 7th ed. New York: McGraw-Hill; 2016.

8. Poppe KJ. Financial accounting, GAAP, and agriculture. In: Beers G, editor. PACIOLI 3; need for change. The Hague: Agricultural Economics Research Institute; 1996.

9. Ross SA, Westerfield RW, Jaffe J. Corporate finance, 10th edn. New York: McGraw-Hill Irwin; 2013.

10. Wageningen Economic Research: BINternet (Farm Accountancy Data Network, in Dutch). 2019. https://www.agrimatie.nl/Binternet. aspx?|D=4\&Bedrijfstype=9. Accessed 11 May 2020.

11. KWIN. Kwantiatieve Informatie Veehouderij 2017-2018 (in Dutch). Lelystad: Wageningen Livestock Research; 2017.

12. PV H, Meulen HVd, Wisman A. Indicatie economische gevolgen fipronilaffaire voor de pluimveesector. Wageningen Economic Research: Wageningen; 2017. 
13. Poultry Expertise Centre. Ervaringen van, met en rond het Fipronil meldpunt Gelderse Vallei. Barneveld: Poultry Expertise Centre; 2018.

14. van Asselt ED, van Bussel $L G$, van Horne $P$, van der Voet $H$, van der Heijden GW, van der Fels-Klerx HJ. Assessing the sustainability of egg production systems in The Netherlands. Poult Sci. 2015;94(8):1742-50. https://doi. org/10.3382/ps/pev165.

15 Reich $\mathrm{H}$, Triacchini GA. Occurrence of residues of fipronil and other acaricides in chicken eggs and poultry muscle/fat. EFSA J. 2018;16:5. https:// doi.org/10.2903/j.efsa.2018.5164.

16. Saatkamp HW, Mourits MCM, Howe KS. A framework for categorization of the economic impacts of outbreaks of highly contagious livestock diseases. Transbound Emerg Dis. 2016;63(4):422-34. https://doi.org/10.1111/ tbed.12286.
17. Mathew L. Coping with shame of poverty: analysis of farmers in distress. Psychol Dev Soc. 2010;22(2):385-407. https://doi.org/10.1177/09713 3361002200207.

18. Gorgievski MJ, Bakker AB, Schaufeli WB, van der Veen HB, Giesen CWM. Financial problems and psychological distress: investigating reciprocal effects among business owners. J Occup Org Psychol. 2010;83(2):513-30. https://doi.org/10.1348/096317909X434032.

\section{Publisher's Note}

Springer Nature remains neutral with regard to jurisdictional claims in published maps and institutional affiliations.
Ready to submit your research? Choose BMC and benefit from:

- fast, convenient online submission

- thorough peer review by experienced researchers in your field

- rapid publication on acceptance

- support for research data, including large and complex data types

- gold Open Access which fosters wider collaboration and increased citations

- maximum visibility for your research: over $100 \mathrm{M}$ website views per year

At BMC, research is always in progress.

Learn more biomedcentral.com/submissions 